\title{
Ectopic forms of schistosomiasis mansoni in the second macroregion of Alagoas: case series report and review of the literature
}

\author{
Carlos William Rodrigues Lima[1], Nathalie Macêdo Cruz de Oliveira ${ }^{[1]}$, \\ Simone Vicente Dias da Silva ${ }^{[1]}$, Maria Eugênia Leite Duarte ${ }^{[2]}$ \\ and Ana Paula Fernandes Barbosa ${ }^{[3]}$
}

\begin{abstract}
[1]. Departamento de Medicina, Universidade Federal de Alagoas, Campus Maceió, Maceió, AL, Brasil. [2]. Divisão de Pesquisa, Instituto Nacional de Traumatologia e Ortopedia, Rio de Janeiro, RJ, Brasil.

[3]. Departamento de Patologia, Universidade Federal de Alagoas, Campus Maceió, Maceió, AL, Brasil.
\end{abstract}

\begin{abstract}
Introduction: Ectopic forms of schistosomiasis are those in which the parasitic element is localized outside the portal system, the natural habitat of the helminth. Although the prevalence rates of schistosomiasis are high in Brazil, clinical and epidemiological data on ectopic forms of the disease are still scarce. Methods: Cross-sectional, retrospective and descriptive epidemiological study in which cases with a confirmed histopathological diagnosis of an ectopic form of schistosomiasis were analyzed. The cases were selected from a database of the anatomic pathology files of a referral center. Results: Of the 21 cases identified, seven affected the female genital tract and five the male genital tract; four cases were identified in the peritoneum; two cases involved lymph nodes and two involved adipose tissue; and renal involvement was detected in one case. Conclusions: The lack of knowledge of the clinical presentation of ectopic forms of schistosomiasis makes the early identification and treatment of this form difficult, with direct implications in the reduction of morbidity and mortality in endemic areas.
\end{abstract}

Keywords: Schistosoma mansoni. Ectopic mansonic schistosomiasis. Pathology. Endemic diseases.

\section{INTRODUCTION}

Schistosomiasis is an infectious granulomatous disease caused by helminths of the genus Schistosoma, with Schistosoma mansoni being the causative agent in Brazil. Originally described in 1851 in Egypt by Theodor Bilharz, schistosomiasis spread from Africa to other continents following migratory flows ${ }^{1}$. Today, according to the World Health Organization (WHO), schistosomiasis ranks second in the world in importance and socioeconomic repercussion, after malaria. It is estimated that schistosomiasis affects 200 million people and poses a threat to more than 600 million individuals living in areas with high endemicity ${ }^{2}$.

Endemic schistosomiasis mansoni occurs in 54 countries located mainly in Africa, the Eastern Mediterranean and the Americas. In South America, it occurs mainly in the Caribbean region, Venezuela and Brazil ${ }^{2,3}$.

In Brazil, the disease occurs in 19 states, covering an endemic area ranging from Maranhão to Espírito Santo and

Corresponding author: Dr. Carlos William Rodrigues Lima.

e-mail:william.rl@hotmail.com

Received 9 April 2017

Accepted 30 November 2017
Minas Gerais, with local outbreaks in other states ${ }^{4}$. However, the magnitude of infection with Schistosoma spp. is heterogeneous. Precarious or nonexistent conditions of basic sanitation, poverty and low levels of schooling characterize the most affected areas. The prevalence of schistosomiasis is particularly higher in the Northeastern States and Minas Gerais ${ }^{6,7}$.

The extensive geographic distribution of schistosomiasis mansoni in Brazil, by itself, provides a dimension of the magnitude of this problem for public health ${ }^{1}$. It is estimated that 2.5 to 8 million Brazilians have the disease. However, knowledge about the epidemiological behavior of this parasitosis is limited, with divergent estimates of its prevalence in the country ${ }^{4}$.

Poor socioeconomic conditions, difficulties in accessing health services, migratory movements and poor conditions of water and sewage treatment are among the main factors responsible for the transmission of schistosomiasis in endemic areas. In Northeast Brazil, the State of Alagoas has the highest prevalence ${ }^{6}$.

According to data from the National Health Foundation (FUNASA), through the Schistosomiasis Control Program in Alagoas, there was a resurgence of the endemic disease ${ }^{7}$, aggravated by socioeconomic conditions unfavorable to disease control $^{8}$. Sixty-nine percent of the municipalities within the state 
are high-endemic areas for schistosomiasis, with more than two and a half million people living at risk of the disease ${ }^{8}$. Among 18 states in the Northeast and Southeast, the highest positivity rates of parasitological tests for schistosomiasis were found in Alagoas ${ }^{9}$.

Currently, 72 municipalities in Alagoas are concentrated in the so-called risk zone for schistosomiasis. In addition, it is possible that an endemic expansion is occurring in the Alagoas municipalities located near the Mundaú and Paraíba river basins. The state is rich in water resources, and the main focuses of the disease are concentrated in the basins of these rivers ${ }^{7,9}$.

The ectopic forms of schistosomiasis are those in which the parasitic elements - eggs or adult worms - are located outside the portal system, the natural habitat of the helminth ${ }^{10}$. Rarely, schistosomiasis occurs in only one isolated organ. In most cases there are lesions in other sites besides the liver and the intestine. The lesions outside this location are seen in up to $20 \%$ of patients, isolated or in association with hepatic and intestinal involvement ${ }^{11}$. However, ectopic forms often do not raise clinical suspicion and usually represent findings in biopsies or necropsies ${ }^{10,11}$.

Classically, the histopathological diagnosis of $S$. mansoni infection is based on the presence of granulomas containing in the central portion the eggs or fragments of S. mansoni eggs, peripherally surrounded by a variable number of multinucleated giant cells, histiocytes, lymphocytes, and eosinophils ${ }^{11}$.

Considering the large number of factors involved in the endemic form of schistosomiasis mansoni in Brazil and the paucity of clinical and epidemiological data on the ectopic forms of the disease ${ }^{8}$, this study aimed to investigate this form of presentation of schistosomiasis in a particular geographic region in the State of Alagoas.

\section{METHODS}

\section{Ethical considerations}

This cross-sectional, retrospective and descriptive epidemiological study was approved by the Research Ethics Committee of the Federal University of Alagoas (CAAE: 1.568.537).

The sample of the present study was selected by an active search in the database of Center of Cancer Prevention and Diagnosis [Núcleo de Prevenção e Diagnóstico do Câncer (NPDC)], Arapiraca, Alagoas, in order to identify all anatomopathological examinations diagnosed with ectopic schistosomiasis from January 2000 to December 2015.

The state of Alagoas has two macroregions established by the Unified Health System (SUS), and the second macroregion of Health covers four regions (from the $7^{\text {th }}$ to the $10^{\text {th }}$ that correspond to the sertão and agreste characterized by a semiarid and harsh climate). These regions are identified as a continuous geographical space made up of groups of neighboring municipalities, delimited by the existence of cultural, economic and social identities, as well as in the areas of communication, infrastructure, transportation and health services. The second macroregion has 1,026,693 inhabitants and its main reference is the City of Arapiraca ${ }^{12}$. NPDC is the only laboratory of anatomic pathology that serves this geographical region, and because it is the only regional destination of human specimens for anatomopathological analysis, it confers on its collection a representative character of this entire region of the state.

For the purposes of inclusion in this study, we considered lesions diagnosed in samples from biopsies or in surgical specimens from organs or tissues located outside the portal system as ectopic forms of schistosomiasis. After identifying ectopic forms of the disease, the histopathological diagnoses were confirmed by two experienced pathologists who were unaware of the initial diagnoses of the lesions. Cases with and without clinical suspicion of ectopic schistosomiasis were included in the series. Patient information (age, gender, ethnicity, municipality of residence, and association of schistosomiasis with other clinical conditions) and the characteristics of the lesion (location, macroscopic description of the surgical specimen and histopathological finding) were recorded in a standardized form. Patients from geographic regions outside the perimeter of the second health macroregion of Alagoas and cases diagnosed outside the period delimited in the study were not included in the series.

The results were expressed as numbers and analyzed by the frequency distribution of the ectopic forms in relation to the demographic and clinical variables of the patients.

\section{RESULTS}

From the survey of the NPDC database, 159,474 histopathological reports were issued between January 2000 and December 2015, of which 174 cases with confirmed diagnoses of schistosomiasis were identified. From this number, five cases were excluded, corresponding to patients from a geographical region outside the perimeter of the second health macroregion of Alagoas. Of the 169 cases identified in the geographic region of interest of this study, 148 were diagnosed in an organ with venous drainage within the portal system (Figure 1).

Ectopic forms of the disease were diagnosed in 21 samples from 20 patients (two samples came from one patient) corresponding to $12.4 \%$ of cases diagnosed as schistosomiasis in the geographic region of the study. The diagnoses were established in biopsies performed due to several clinical indications, and there was no suspicion of schistosomiasis in any of the cases. Thus, in the entire sample, the diagnosis of the ectopic form was a histopathological finding. The demographic and clinical characteristics of the patients are described in Table 1.

Of the twenty patients 11 were men; age ranged from 24 to 103 years and the most common ectopic form of schistosomiasis was that of the female genital tract (7/21). Of the seven cases diagnosed in this region, three were in the uterus, with two localized in the uterine cervix, one associated with infiltrating carcinoma, one associated with chronic cervicitis (Figure 2A) and one in the uterine body associated with leiomyoma. In the four cases diagnosed in the ovary, we observed association with oophoritis in one case, cystic teratoma in one case, endometriosis in one case, and follicular cyst in one case. 


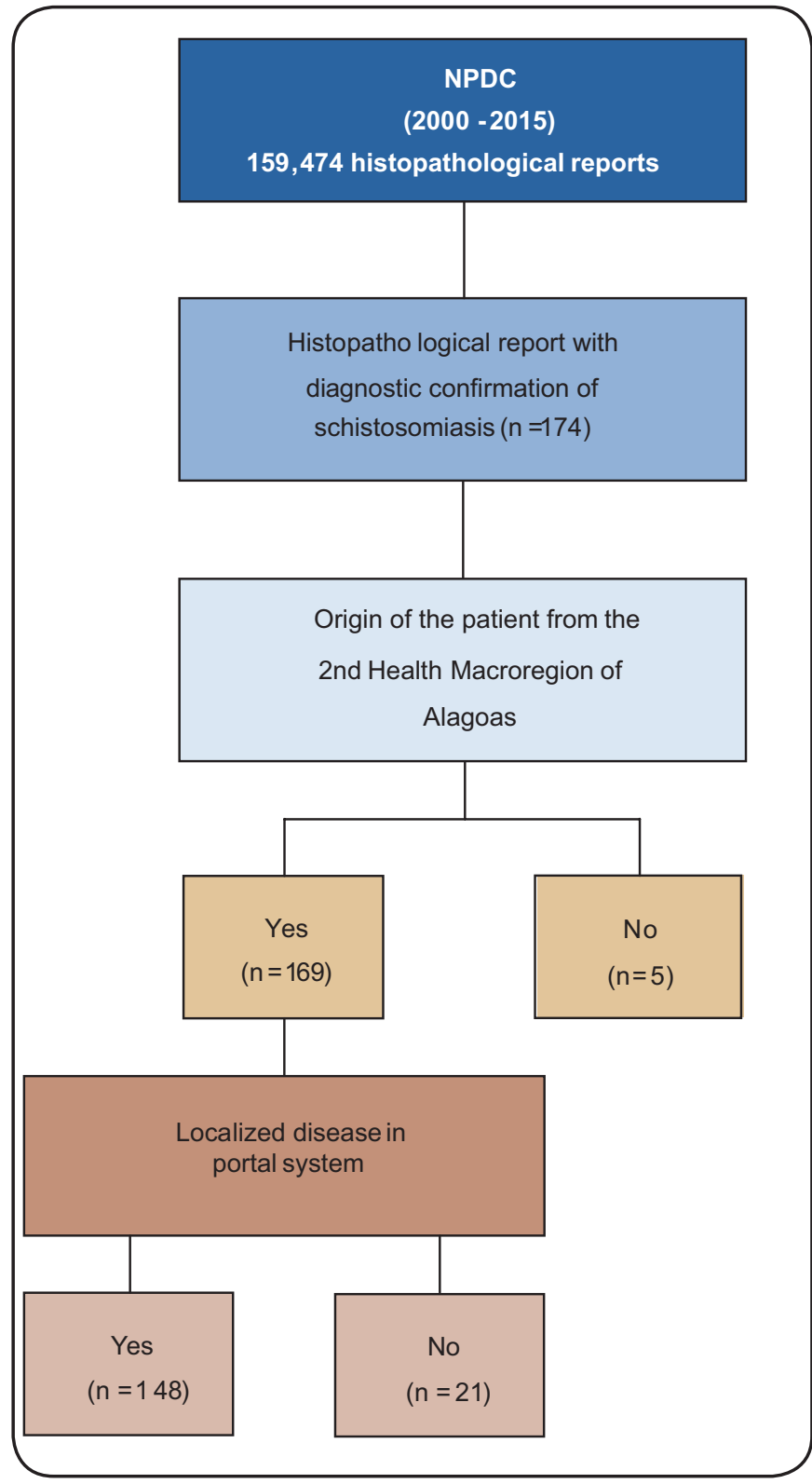

FIGURE 1 - Ectopic schistosomiasis in NPDC - Alagoas second macroregion: flowchart of case inclusion. NPDC: Núcleo de Prevenção e Diagnóstico do Câncer.

Involvement of the male genital tract was observed in five cases; in three cases, the lesions were located in the testis (in two patients orchiectomy was performed due to adenocarcinoma of the prostate and in one patient there was association with chronic orchitis), in one case it was localized in the penis in association with squamous cell carcinoma (Figure 2B), and in one it was localized in the epididymis and was associated with epididymitis.

In the abdominal cavity, the ectopic form was diagnosed in three cases in the visceral peritoneum (colonic serosa including one case of pseudotumoral form); in the omentum it was diagnosed in a patient who underwent radical gastrectomy due to adenocarcinoma, presented also as a pseudotumoral lesion
TABLE 1: Demographic data of patients with ectopic forms of schistosomiasis

\begin{tabular}{|c|c|c|c|c|}
\hline Case & Gender & Age & Topography & $\begin{array}{l}\text { Associated } \\
\text { clinical } \\
\text { conditions }\end{array}$ \\
\hline 1 & $\mathrm{~F}$ & 56 & Uterine body & Leiomyoma \\
\hline 2 & $\mathrm{~F}$ & 37 & Cervix & Chronic cervicitis \\
\hline 3 & $\mathrm{~F}$ & 42 & Cervix & $\begin{array}{c}\text { Poorly } \\
\text { differentiated } \\
\text { carcinoma }\end{array}$ \\
\hline 4 & $\mathrm{~F}$ & 35 & Ovary & Oophoritis \\
\hline 5 & $\mathrm{~F}$ & 28 & Ovary & Cystic teratoma \\
\hline 6 & $\mathrm{~F}$ & 26 & Ovary & Endometriosis \\
\hline 7 & $\mathrm{~F}$ & 39 & Ovary & Follicular cysts \\
\hline 8 & M & 103 & Testis & $\begin{array}{c}\text { Prostrate } \\
\text { adenocarcinoma }\end{array}$ \\
\hline 9 & $\mathrm{M}$ & 87 & Testis & $\begin{array}{c}\text { Prostrate } \\
\text { adenocarcinoma }\end{array}$ \\
\hline 10 & M & 93 & Testis & Chronic orchitis \\
\hline 11 & M & 82 & Penis & $\begin{array}{l}\text { Epidermoid } \\
\text { carcinoma }\end{array}$ \\
\hline 12 & $\mathrm{M}$ & 47 & Epididymis & Epididymitis \\
\hline 13 & $\mathrm{M}$ & 55 & $\begin{array}{l}\text { Sigmoid colon } \\
\text { (serous membrane) }\end{array}$ & $\begin{array}{l}\text { Pseudotumoral } \\
\text { form }\end{array}$ \\
\hline 14 & M & 48 & $\begin{array}{l}\text { Sigmoid colon } \\
\text { (serous membrane) })^{1}\end{array}$ & - \\
\hline 15 & $\mathrm{~F}$ & 30 & $\begin{array}{l}\text { Descending colon } \\
\text { (serous membrane) }\end{array}$ & - \\
\hline 16 & M & 39 & Omentum & $\begin{array}{l}\text { Pseudotumoral } \\
\text { form + Gastric } \\
\text { adenocarcinoma }\end{array}$ \\
\hline 17 & $\mathrm{M}$ & 67 & Perigastric fat & $\begin{array}{c}\text { Gastric } \\
\text { adenocarcinoma }\end{array}$ \\
\hline 18 & $\mathrm{~F}$ & 41 & Pelvic fat & $\begin{array}{l}\text { Carcinoma in } \\
\text { situ of the cervix }\end{array}$ \\
\hline 19 & M & 48 & Mesosigmoid lymph node* & $\begin{array}{c}\text { Colon } \\
\text { adenocarcinoma }\end{array}$ \\
\hline 20 & $\mathrm{M}$ & 24 & Lymph node & $\begin{array}{l}\text { Traumatic } \\
\text { rupture of } \\
\text { rectosigmoid }\end{array}$ \\
\hline 21 & $\mathrm{M}$ & 41 & Kidney & $\begin{array}{l}\text { Clear cell } \\
\text { carcinoma }\end{array}$ \\
\hline
\end{tabular}

*Same patient with simultaneous presentation of two ectopic forms (sigmoid colon serosa and mesosigmoid lymph node).

(Figure 2C). The ectopic form diagnosed in the adipose tissue of two patients corresponded to the fat surrounding lymph nodes isolated from the perigastric and pelvic regions, removed during a surgical procedure for the treatment of gastric adenocarcinoma and carcinoma in situ of the uterine cervix, respectively. 


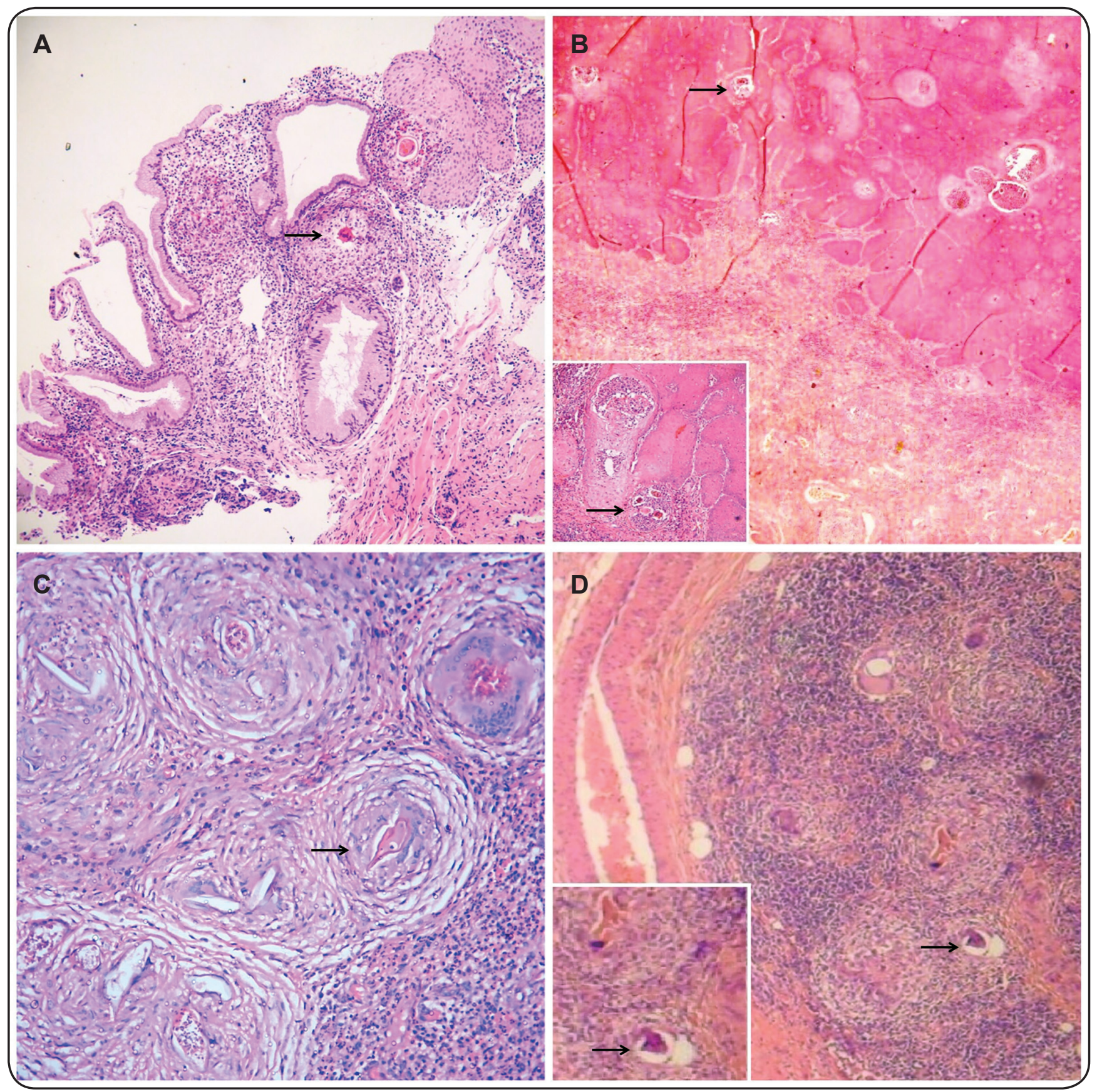

FIGURE 2 - Histopathological findings of the ectopic forms of schistosomiasis mansoni. Hematoxylin and eosin staining. A: Uterine cervix of a 37-yearold woman displaying granulomas surrounding eggs of S. mansoni (arrow) and cervicitis (HE, 10× objective). B: Penile glans of an 82-year-old man displaying an infiltrating epidermoid carcinoma ( $\mathrm{HE}, 4 \times$ objective). The inset shows at higher magnification the granulomas containing $S$. mansoni eggs (arrow) in close association with the neoplastic cells (HE, 20x objective). C: Omentum of a 39-year-old man displaying the pseudoneoplastic form of ectopic schistosomiasis mansoni with an exuberant granulomatous reaction involving S. mansoni eggs (arrow) (HE, 40× objective). D: Mesosigmoid lymph node of a 48-year-old man showing granulomatous reaction surrounding $S$. mansoni eggs (HE, 10× objective). The inset shows detail from the granulomas containing S. mansoni eggs (arrow) (HE, 20× objective). S. mansoni: Schistosoma mansoni; HE: hematoxylin and eosin.

Lymph node involvement was seen in two cases, in one lymph node removed during a surgical procedure for the treatment of gastric adenocarcinoma (Figure 2D), and the other was removed during a procedure for surgical treatment of traumatic rupture of the rectosigmoid colon. In the patient diagnosed with cancer, there was no evidence of metastatic infiltration of the lymph node by the neoplasia). Renal involvement was seen in one case in association with primary renal carcinoma (renal cell carcinoma, clear cell type).

\section{DIscussion}

Female genital schistosomiasis is common in endemic areas, but there are few reports in the Brazilian and global medical literature ${ }^{13}$. Recently, the WHO has included female genital 
schistosomiasis in the category of gender-specific diseases that deserve priority research ${ }^{13}$. It is estimated that $6-27 \%$ of girls and women with intestinal schistosomiasis suffer from pathological conditions induced by eggs entrapped in parts of the genital tract ${ }^{13,14}$.

The mechanism by which $S$. mansoni eggs reach the female genital tract is not fully understood ${ }^{15}$. However, it is believed that the anastomoses between the hemorrhoidal veins and vessels that drain the internal genitalia and vulva allow the migration of worms and egg embolization into the capillary bed, where they induce the formation of granulomas ${ }^{14-16}$.

Data on the topographic distribution of genital schistosomiasis in Brazil and in other countries show the involvement of the following organs, in descending order of importance: ovaries, cervix, uterus, uterine tubes, vulva, and vagina ${ }^{13}$. In our series, female genital involvement showed a similar proportion of distribution as that described in the literature, with the ovary being the main organ affected (4/7) followed by the cervix (2/7) and the uterine body (1/7).

Schistosoma mansoni eggs when transported to the genital and reproductive tract may give rise to hypertrophic or ulcerative lesions causing female infertility and increased risk of ectopic pregnancy. Lesions may also represent a risk factor for infections due to sexually transmitted diseases, especially human immunodeficiency virus and human papilloma virus ${ }^{13,15,17}$. In the ectopic form of schistosomiasis involving the uterine cervix, postcoital, intermenstrual and post-menstrual bleeding, vaginal discharge and dysmenorrhea can occur - signs that are not direct consequences of schistosomiasis but result from its association with cervicitis (Figure 2A) ${ }^{18}$. However, the involvement of the female genital tract is usually asymptomatic and the eggs are an occasional finding evidenced in histological examinations for different purposes ${ }^{18}$.

Despite the scarcity of reports on the presence of S. mansoni in the male genital tract and the sexual and reproductive impact it can cause in men, ectopic forms have been described in the penis, scrotum, testis, epididymis, spermatic funiculus, seminal vesicle, and prostate. There are also reports of the presence of eggs in human semen ${ }^{19}$.

Although schistosomiasis is endemic in many countries, $S$. mansoni infection with testicular involvement is extremely rare $^{20}$. Its occurrence is attributed to the migration of eggs through the venous channels between the mesenteric veins and the internal spermatic vein, inducing an immune response and formation of granulomas associated with fibrotic changes ${ }^{20,21}$.

In an autopsy study performed in an endemic area of Brazil, testicular involvement was observed in $3.2 \%$ of cases of schistosomiasis ${ }^{22}$. However, in this location schistosomiasis may be clinically characterized by unilateral testicular edema, gonadal atrophy, libido alterations, erectile dysfunction, infertility, and testicular nodulations, mimicking a neoplastic lesion that may in certain circumstances lead to unnecessary orchidectomy $\mathrm{y}^{20,21,23,24}$.

In endemic areas it is fundamental to maintain a high degree of suspicion of testicular schistosomiasis as a differential diagnosis of testicular tumors in boys or adult males with a testicular mass ${ }^{20,25}$. The indication of radical orchiectomy should be carefully reviewed to avoid unnecessary invasive surgeries, especially in patients of reproductive age. In this context, partial orchiectomy with intraoperative frozen section examination may be a safe and effective approach for the diagnosis and treatment of these benign lesions ${ }^{20}$.

There is only one case described in the literature of ectopic presentation of S. mansoni eggs in the epididymis ${ }^{26}$. However, schistosomiasis of the epididymis due to S. haematobium is not uncommon in areas endemic for the disease and is usually associated with rectal or vesical schistosomiasis. Although there may be scrotal pain, hardening or enlargement of the organ associated with epididymitis ${ }^{21,26}$, it is usually asymptomatic even in the advanced form of the disease, which may explain the small number of cases reported in the literature ${ }^{27}$.

Penile involvement in S. haematobium infection through sexual transmission is a possibility that was raised a few decades $\mathrm{ago}^{28}$. The suggested mechanism would be the transference of eggs through the contact of the penis with the affected cervix or indirectly by the release of eggs through the female urethra. In this report, the authors described that the infection of the penis by $S$. haematobium results in fibrosis of the cavernous tissue, organ stiffness, urinary obstruction and extensive tissue destruction, simulating early carcinoma of the penis ${ }^{28}$. However, we did not find in the literature the association of S. mansoni, the only species found in Brazil, and ulcerative infiltrating squamous cell carcinoma of the penis (Figure 2B).

Further studies on the urogenital system are needed to assess the real significance of male genital lesions and a systematic study among men with schistosomiasis mansoni to establish the prevalence of urogenital localization ${ }^{19}$.

Schistosomiasis has been associated with some forms of neoplasias ${ }^{29}$. The most striking association occurs in areas with a high prevalence of urinary schistosomiasis due to S. haematobium, such as Africa and the Middle East. In these regions there is a predominance of squamous cell carcinoma of the bladder, a relatively rare form of cancer in non-endemic regions $^{29,30}$. In China, where colorectal cancer reaches relatively high incidence rates in endemic areas, the association between this type of neoplasia and diffuse colitis due to S. japonicum infection has also been suggested ${ }^{30,31}$. Some isolated case reports describe the association between adenocarcinoma of the prostate and prostate infection by S. haematobium and S. mansoni. However, the epidemiological relationship between the two conditions remains limited to the few published cases ${ }^{30-32}$.

In our series we observed the association of the ectopic form of schistosomiasis with a benign neoplasia in two cases (uterine leiomyoma and ovarian cystic teratoma). The association with malignant neoplasia was observed in nine cases. In three patients (squamous cell carcinoma of the penis, carcinoma of the uterine cervix and renal cell carcinoma) there was an intimate association between neoplastic cells and $S$. mansoni eggs. It is possible that local hypervascularization related to tumor growth facilitates the migration of the eggs resulting in the simultaneous association, without causal relationship, between the two conditions. 
The ectopic forms of S. mansoni affecting the peritoneum are usually associated with the hyperplastic manifestations of the disease (pseudotumoral form) that seems to be directly related to the egg of the parasite. In these circumstances the egg acts as an antigenic complex, which would provoke an exaggerated granulomatous inflammatory response in the organism ${ }^{33,34}$. As the oviposition of worms occurs in the descending colon, sigmoid colon and rectum, the ectopic lesions are located mainly in relation to this

topography ${ }^{34,35}$. Our results confirm both the association of the peritoneal lesion with the pseudotumoral form of schistosomiasis (Figure 2C) and with the topographic relation with the sigmoid and descending colon.

There is only one report describing the presence of $S$. mansoni eggs in the omentum of humans ${ }^{36}$. However, in experimental studies in mice, after direct intraperitoneal inoculation of the parasite there was evidence of eggs in the omentum and peritoneum ${ }^{37}$. These findings suggest that the parasite is able to develop without ingestion of red blood cells (intravascular localization) and may explain the presence of Schistosoma eggs in human omentum.

Only two cases of ectopic forms of Schistosoma with lymph node involvement have been reported in the literature published in the English language ${ }^{38,39}$. In one report, eggs from $S$. japonicum were found in the mesenteric lymph nodes associated with carcinoma of the sigmoid colon ${ }^{38}$. In the other, which is the first report of lymph node involvement by Schistosoma eggs, there was an association between the granulomas and pericolic lymphadenitis ${ }^{39}$. Until then it was believed that the lymph nodes were resistant to such involvement due to the small diameter of the vessels in relation to the size of the eggs, due to the spicules of the eggs, making vascular migration difficult or by an indirect suppressive mechanism of the immune system that would inhibit granuloma formation in the lymph nodes ${ }^{39}$. In our study we observed lymph node involvement by $S$. mansoni in a patient with a malignant neoplasm of the colon. Despite the topography of the lymph node in the territory of organ drainage, the lesion in the lymph node was represented only by the granulomatous component, without neoplastic involvement (Figure 2D).

Only one case of ectopic presentation in adipose tissue is reported in the literature ${ }^{40}$. In this report the ectopic form was described and a lipoma located in the subcutaneous tissue, distant from the life cycle of the worm and without connection with any portal vein or another vascular system that could to be used for its migration ${ }^{40}$. The two cases reported in our study, on the contrary, were described in the perigastric and pelvic adipose tissue and could be explained by the migration of worms and/ or egg embolization through vascular anastomoses.

The prevalence of renal involvement in schistosomiasis is variable and is related to the profile of the study population ${ }^{41}$. The pathophysiology of renal injury in schistosomiasis has features common to other parasitic diseases, such as malaria. Kidney damage is mainly caused by glomerulopathy mediated by the deposition of immune complexes formed by circulating Schistosoma antigens and antibodies against the parasite ${ }^{41}$.
Considering all forms of the disease, the incidence of glomerular involvement is estimated at $5-6 \%$ and increases by $15 \%$ in the hepatosplenic form of the disease ${ }^{41,42}$. Despite the established association between schistosomiasis and glomerulopathy by immunocomplexes, the kidneys are rare sites of granuloma formation and the contribution of ectopic schistosomiasis to renal damage remains poorly understood ${ }^{43,44}$. In our series, the only case of ectopic schistosomiasis in the kidney occurred in association with renal cell carcinoma, with no involvement of the renal parenchyma. The inflammatory process, represented by the presence of granulomas, was identified solely in the neoplastic tissue.

Early identification of the disease and timely treatment of $S$. mansoni infected patients are the main measures in reducing the disease morbidity and mortality. However, ectopic forms of the disease are usually initially silent. Thus, this study reinforces the epidemiological importance of the diagnosis of the ectopic form of schistosomiasis mansoni and the need for health professionals to be aware of this form of presentation. Thus, the diagnosis of new cases of ectopic schistosomiasis, especially in endemic areas should be reported and investigated, as they also function as markers of critical areas that need prioritization and basic care integrated actions.

The remarkable number of cases of ectopic schistosomiasis and the variety of anatomical location described in our study may be explained by the high endemic rates of schistosomiasis in this geographic region. Considering that the prevalence of $S$. mansoni in municipalities of the northeastern states of Brazil is still high, it is believed that low notification rates and lack of protocols tailored to the investigation of ectopic forms are responsible for the absence of diagnoses of ectopic forms of this parasitic disease ${ }^{15}$. Also, it would be advisable to maintain a high degree of diagnostic suspicion to identify ectopic forms of the disease.

\section{Acknowledgments}

We would like to thank Universidade Federal de Alagoas (UFAL) and Núcleo de Prevenção e Diagnóstico do Câncer (NPDC) that provided support for the development of this study.

\section{Conflict of interest}

The authors declare that there is no conflict of interest.

\section{REFERENCES}

1. Christinet V, Helds JKL, Stothard JR, Rupp JR. Female genital schistosomiasis (FGS): from case reports to a call for concerted action against this neglected gynaecological disease. Int J Parasitol. 2016;46(7):395-404.

2. Ministério da Saúde (MS). Secretaria de Vigilância em Saúde. Vigilância da Esquistossomose Mansoni: Diretrizes técnicas. Brasília: MS; 2014.

3. Ministério da Saúde (MS). Secretaria de Vigilância em Saúde. Guia de vigilância epidemiológica. Brasília: MS; 2009. 
4. Cantanhede SPD, Ferreira AP, Mattos IE. Esquistossomose mansônica no Estado do Maranhão, Brasil, 1997-2003. Cad Saúde Pública. 2011;27(4):811-16.

5. Nascimento GL. Formas graves da esquistossomose mansoni: carga epidemiológica e custos no Brasil em 2010 [master's thesis]. Brasília: Universidade de Brasília; 2013. 73 p.

6. Silva PCV, Domingues ALC. Aspectos epidemiológicos da esquistossomose hepatoesplênica no Estado de Pernambuco, Brasil. Epidemiol. Serv Saúde. 2011;20(3):327-36.

7. Couto JLA. Esquistossomose mansoni em duas mesorregiões do Estado de Alagoas. Rev Soc Bras Med Trop. 2005;38(4):301-4.

8. Jordão MCC, Macêdo VKB, de Lima AF, Xavier Junior AFS. Caracterização do perfil epidemiológico da esquistossomose no estado de Alagoas. Cad Grad Ciên Biol Saude. 2014;2(2):175-88.

9. Palmeira DCC, Carvalho AG, Rodrigues K, Couto JLA. Prevalência da infecção pelo Schistosoma mansoni em dois municípios do Estado de Alagoas. Rev Soc Bras Med Trop. 2010;43(3):313-17.

10. Souza FPC, Vitorino RR, Costa AP, Júnior FCF, Santana LA, Gomes AP. Esquistossomose mansônica: aspectos gerais, imunologia, patogênese e história natural. Rev Bras Clin Med. 2011;9(4):300-7.

11. Raso P. Esquistossomose mansônica. In: Filho GB, editor. Bogliolo Patologia. $7^{\text {th }}$ edition. Rio de Janeiro: Guanabara-Koogan; 2006. p. $1358-59$.

12. Secretaria de Estado da Saúde. Plano Diretor de Regionalização (PDR). Maceió: SESAU; 2011.

13. Lambertucci JR, Villamil QTMF, Savi D, Dias IC. Genital schistosomiasis mansoni: tubal tumor and parietal peritoneum involvement diagnosed during laparoscopy. Rev Soc Bras Med Trop. 2009;42(5):583-6.

14. Feldmeier H, Daccal RC, Martins MJ, Soares V, Martins R. Genital manifestations of schistosomiasis mansoni in women: important but neglected. Mem Inst Oswaldo Cruz. 1998;93(1):127-33.

15. Delmondes LM, Cruz MA, Guimarães MK, Santana LG, Gonçalves VP, Brito HL. Esquistossomose endocervical: relato de caso. Rev Bras Ginecol Obstet. 2014; 36(6):276-80.

16. Kjetland EF, Leutscher PDC, Ndhlovu PD. A review of female genital schistosomiasis. Trends Parasitol. 2012;28(2):58-65.

17. Gryseels BMAJ. Schistosomiasis. Infect Dis Clin North Am. 2012;26(2):383-97.

18. Badiale GB; Brandão DF; Silva AR. Esquistossomose endocervical. Rev Soc Bras Med Trop. 2005;38(4):351-2.

19. Rubens Campos R, Cimieiman B, Fiocchi C, Inácio W. Nota sobre o encontro de ovos de $S$. mansoni no esperma. Rev Soc Bras Med Trop. 1971;5(6):315-7.

20. Ferreira TN, Higa HCM, Rondina RG, Miranda MML, Kaddoun ML, Santos MCFLS, Souza RSM de. Testicular schistosomiasis as differential diagnosis for testicular nodules: a case report. Rev Soc Bras Med Trop. 2015;48(4):501-3.

21. Lopes RI, Leite KR, Prando D, Lopes RN. Testicular Schistosomiasis Caused by Schistosoma mansoni: A Case Report from Brazil. BJID. 2007;11(5):523-4.

22. Gonçalves EC, Fonseca AP, Pitella JE. Frequency of schistosomiasis mansoni, of its clinicopathological forms and of the ectopic locations of the parasite in autopsies in Belo Horizonte, Brazil. J Trop Med Hyg. 1995;98(5):289-95.

23. Rambau PF, Chandika A, Chalya PL, Jackson K. Scrotal swelling and testicular atrophy due to schistosomiasis in a 9-year-old boy: a case report. Case Rep Infect Dis. 2011(2011):Article ID 787961.
24. Adisa J, Egbujo EM, Yahaya BA, Echejoh G. Primary infertility associated with Schitosoma mansoni: a case report from the Jos plateau, north central Nigeria. Afr Health Sci. 2012;12(4):563-5.

25. Ekenze SO, Modekwe VO, Nzegwu MA, Ekpemo SC, Ezomike UO. Testicular schistosomiasis mimicking malignancy in a child: a case report. J Trop Pediatr. 2015;61(4):304-9.

26. Alves LS, Assis BPS, Rezende MMB. Schistosomal Epididymitis. Int Braz J Urol. 2004;30(5):413-5.

27. Eltayeb AA. Schistosomal of the Epididymis. Brit J Surg. 1969;56(7):552-3.

28. Badejo OA, Soyinka F, Laja AO. Ectopic lesion of schistosomiasis of the penis simulating an early carcinoma. Acta Trop. 1978;35(3):2637.

29. Lopes EJA, Almeida CAR, Jacobino M. Esquistossomose mansônica em vesícula seminal. Rev Soc Bras Med Trop. 2007;40(3):341-2.

30. Basílio-de-Oliveira CA, Aquino A, Simon EF, Eyer-Silva WA. concomitant prostatic schistosomiasis and adenocarcinoma: case report and review. BJID. 2002;6(1):45-9.

31. Bacelar A, Castro LGMC, Queiroz AC, Café E. Association between prostate cancer and schistosomiasis in young patients: a case report and literature review. Braz J Infect Dis. 2007;11(5):520-2.

32. Mazigo HD, Zinga M, Heukelbach J, Rambau P. Case series of adenocarcinoma of the prostate associated with Schistosoma haematobium Infection in Tanzania. J Glob Infect Dis. 2010;2(3):307-9.

33. Kalil M, Neto OB, Vieira LCA, Cintra LC. Forma Pseudotumoral Intra-Abdominal da Esquistossomose Mansônica. Rev Col Bras Cir. 2006;33(3):203-4.

34. Santana HJ, Lima CA. Pseudotumor esquistossomótico de cólon: relato de um caso. Rev Bras Colo-Proctol. 1985;5(1):17-21.

35. Bittencourt AL, Sapucaia JBR, Dos Santos WLC. Forma tumoral da esquistossomose mansonica envolvendo o intestino delgado: apresentação de três casos na infância. Acta Med Port. 1983;4:351-4.

36. Konstantinidou E, Alexiou C, Demonakou M, Sakellaridis T, Fotopoulos A, Antsaklis, G. Schistosomal peritonitis: a rare cause of acute abdomen. Trans R Soc Trop Med Hyg. 20091;103(10): 1068-70.

37. Melo AL, Chamone M. Schistosoma mansoni: inflammatory foci around larvae in the peritoneal cavity of naïve mice is radiosensitive. Rev Inst Med Trop Sao Paulo. 2001;43(2):63-5.

38. Li WC, Pan ZG, Sun YH. Sigmoid colonic carcinoma associated with deposited ova of Schistosoma japonicum: A case report. World J Gastroenterol. 2006;12(37):6077-9.

39. Eldin OS, Nada N, Eldosoky I. Bilharzial lymphadenitis, a case report. Histopathology. 2008;52(5):655-6.

40. Sabino KR, Nunes MB, Petroianu A. Ectopic Schistosoma mansoni eggs inside a lipoma. Am J Trop Med Hyg. 2016;94(1):156-7.

41. Junior AGBS, Duarte DB, Barros EJG, Daher EF. Schistosomiasisassociated kidney disease: a review. Asian Pac J Trop Dis. 2013;3(1):79-84.

42. Duarte DB, Vanderlei LA, de Azevêdo Bispo RK, Pinheiro ME, da Silva Junior GB, De Francesco Daher E. Acute kidney injury in schistosomiasis: a retrospective cohort of 60 patients in Brazil. J Parasitol. 2015;101(2):244-7.

43. Dial C, Noël LH. Eggs in the kidney. Kidney Int. 2010;77(10):934.

44. Neves PDMM. Schistosoma mansoni and membranous nephropathy. Kidney Int. 2016;89(4):959. 